\title{
The Study Deformation Of Bore Pile Foundation Caused by Horizontal Load In Soft Clay
}

\author{
Fadel Jehlaeh, Helmy Darjanto, Hendro Sutowijoyo
}

Department of Civil Engineering, Faculty of Engineering, Narotama University, Indonesia

*Corresponding author E-mail: fadel3238@gmail.com

\begin{abstract}
Manuscript received 1 Jan 2021; revised 10 Jan 2021; accepted 15 Jan 2021. Date of publication 20 Jan 2021

A sturdy of building must be contain with a strong foundation, which is able to withstand the burden on it; channel the load into the ground and be able to withstand external forces such as earthquakes. In this study discussed the deformation of the bore pile foundation due to horizontal load on the soil slope by using the Lpile application. The aim is to know the displacement of foundation motion due to horizontal loads using the Lpile application, Lateral bearing capacity analysis which is important aspect in the design of the foundation to anticipate the failure of the pile foundation. One method is the p-y curve, It is a development of the Beam method in the Winkler Foundation.
\end{abstract}

Keywords: Bore pile, application Lpile, horizontal load, p-y curve

\section{Introduction}

Civil structures consist of upper and lower structures [1]. The upper structure consists of construction of columns, beams, plates, etc. Whereas the lower structure consists of foundation in construction. The foundation is the structure of the underside of a building that is directly related to the ground, or a part of the building which is located below the surface of the land which has the function of bearing the burden of other parts of the building above it [2].

One of the foundations that can be used for multi-storey buildings such as malls is the bored pile foundation. Bore Pile foundation is a form of Deep Foundation that is built in the soil with a certain depth.The installation is done by drilling the ground first [3].

The p-y curve method models the soil as a non-linear spring [4]. This method was introduced by McClelland and Focht in 1956 in the form of a curve of the relationship of the soil reaction with deflection due to lateral loads, the $p$-y curve method is more commonly used because the process is not complicated when compared with other methods and the results are reliable [5]. However, the p-y curve method does not take into account the effect of the cross section because the pile is simplified into a one-dimensional pile model with an empirical approach [6].

\section{Literature Review}

\subsection{Foundation}

The foundation is a part of the building that is directly related to the land, and functions as a channeling of building loads to the ground [7]. The foundation usually extends underground. Broadly speaking, the foundation is only divided into 2 types which are shallow foundations and deep foundations. These shallow foundations are used if the burden carried on the soil is not too large whereas deep foundations can be used to transfer loads to deeper soil layers until a soil type that is able to support load on building structures [8].

\subsection{Lateral carrying capacity}

The permissible lateral load can be obtained based on 2 criteria, namely by dividing the ultimate load with a safety factor and based on the maximum allowable deflection. Reese Matlock theory determines ultimate lateral capacity based on lateral deflection clearance, this method uses a subgrade reaction approach. In this method, poles are distinguished by rigid poles (short poles) and elastic poles (long poles) and the condition of the pile heads being squeezed and free. 


\subsection{P-y curve method}

The p-y curve method is one of the settlement methods for analyzing lateral deflection of the pile [9]. This method defines the relationship of lateral loads and deflection between the soil and piles depicted in the p-y curve [10]. The p-axis is the lateral resistance of the pile's long union land and the $y$-axis is the lateral deflection of the pile.

Below are the parameters used to mean applied:

1. $c_{u}$ (Undrained Shear Strength)

The value of cu can be calculated by using the formula $\mathrm{cu}=0.6 \mathrm{~N}(\mathrm{t} / \mathrm{m} 2)$ or $\mathrm{cu}=6 \mathrm{~N}(\mathrm{kPa})$.

2. Shear angle $(\phi)$

Deep shear angle is an angle formed from the relationship between normal stress and shear stress in soil or rock material. Deep shear angle is the fracture angle formed if a material is subjected to a stress or force over it that exceeds the shear stress. The greater the shear angle in a material, the material will be more resistant to accept the outside stress imposed on it. The correlation between NSPT and shear angle according to some experts as follows can be seen in the Figure below:

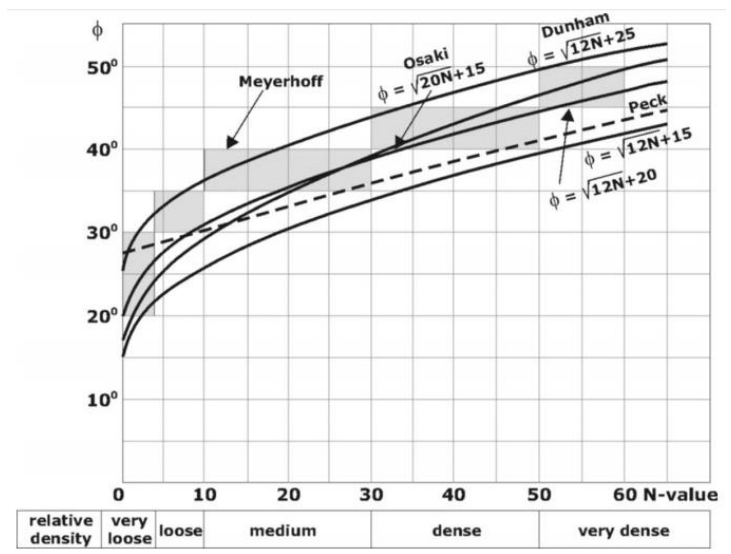

Fig 1. NSPT Correlation and Shear Angle

3. The parameter $\varepsilon 50$

In the $\varepsilon 50$ data it has to be seen in the cu data that has been calculated from the beginning, because the cu data becomes a reference to the $\varepsilon 50$ data can be seen in the Table below:

Table 1. Parameters $\varepsilon 50$

\begin{tabular}{ccc}
\hline Type of soil & $\boldsymbol{c}_{\mathbf{u}}(\mathbf{k P a})$ & $\boldsymbol{\varepsilon s 0}_{\mathbf{5 0}}$ \\
\hline Very soft & $>12$ & 0,02 \\
Soft & $12-24$ & 0,02 \\
Medium & $24-48$ & 0,01 \\
Stiff & $48-96$ & 0,006 \\
Very stiff & $96-192$ & 0,005 \\
Hard & $<192$ & 0,004 \\
\hline
\end{tabular}

\section{Methods}

\subsection{Technical data collection}

Using primary data and secondary data, literature and references.

\subsection{Calculation of foundation}

The type of pole used is the Bore Pile, the shape of the foundation is round $(\mathrm{D}=0.4 \mathrm{~m}$, $\mathrm{A}=0.125664 \mathrm{~m} 2$, circumference $=1.256637 \mathrm{~m}$ ) and the foundation depth $=16 \mathrm{~m}$.

\subsection{Soil data}

soil data used as follows:

Tabel 2. Soil data

\begin{tabular}{cccc}
\hline \multicolumn{4}{c}{ Tabel 2. Soil data } \\
\hline $\begin{array}{c}\text { Depth } \\
(\mathbf{m})\end{array}$ & $\begin{array}{c}\boldsymbol{\Delta} \mathbf{H} \\
(\mathbf{m})\end{array}$ & $\begin{array}{c}\text { Type of } \\
\text { soil }\end{array}$ & NSPT \\
\hline $\mathbf{1}$ & 1 & Silty & 2 \\
$\mathbf{3}$ & 2 & Clay & 1 \\
$\mathbf{7}$ & 4 & Clay & 2
\end{tabular}




\begin{tabular}{cccc}
$\mathbf{1 2 . 5}$ & 5.5 & Clay & 3 \\
$\mathbf{1 6}$ & 3.5 & Sand & 20 \\
$\mathbf{2 0}$ & 4 & Silty & 25 \\
$\mathbf{2 2 . 5}$ & 2.5 & Silty & 26 \\
$\mathbf{2 5}$ & 2.5 & Sand & 35 \\
$\mathbf{2 7}$ & 2 & Sand & 35 \\
$\mathbf{2 9}$ & 2 & Sand & 35 \\
\hline
\end{tabular}

\subsection{Plan load}

The lateral load entered at $23 \mathrm{Kn}$ and $24 \mathrm{kn}$ will make a comparison between these two

\section{Results and Discussion}

From the above data it will be entered into the Lpile application can be seen in the following section:

\subsection{Calculation results of parameters}

Table 3. Result of parameter calculation

\begin{tabular}{cccc}
\hline $\begin{array}{c}\text { Layer Thickness } \\
(\mathrm{m})\end{array}$ & Type of soil & N-SPT & $\gamma$ \\
\hline 12.5 & Solf clay & 3 & 6.8 \\
18 & Sand & 20 & 7 \\
25 & Sand & 35 & 7 \\
\hline
\end{tabular}

Next is to enter all the data needed in the Lpile application can be seen in the next way.

1. Enter foundation data

Foundation data includes pile type, pile dimensions, concrete options and pile reinforcement.

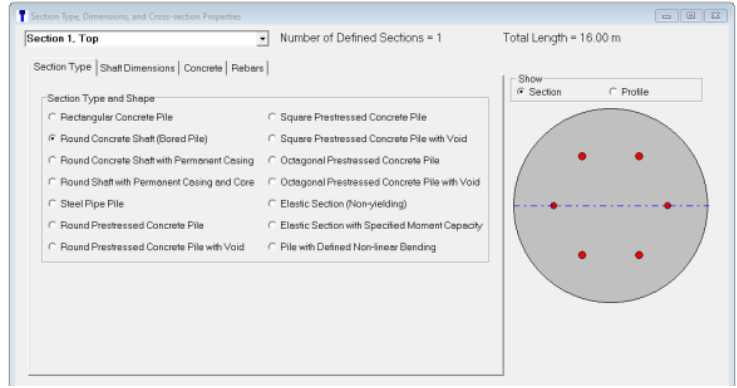

Fig 2. Pile Type

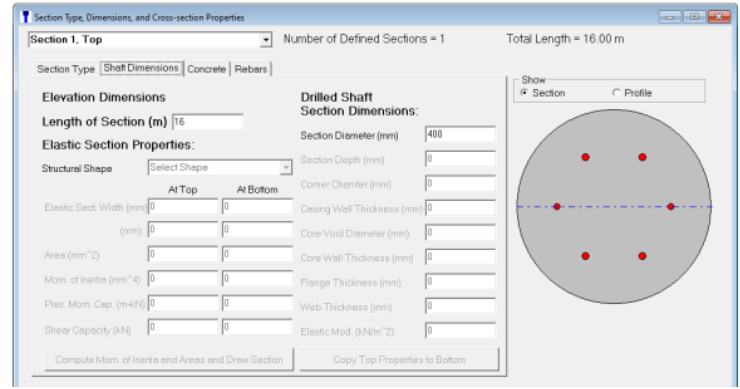

Fig 3. Pile Dimensions 


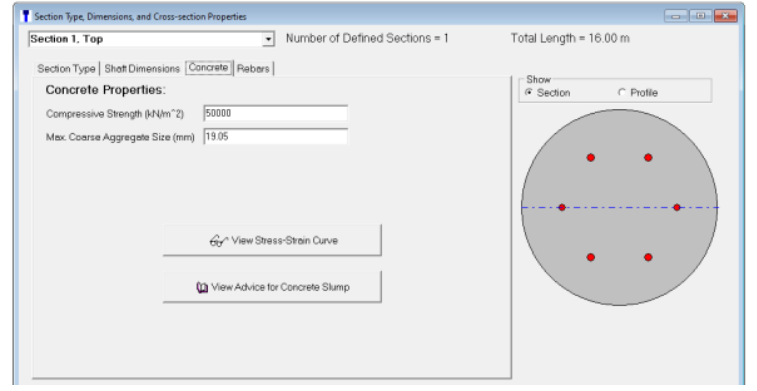

Fig 4. Concrete option

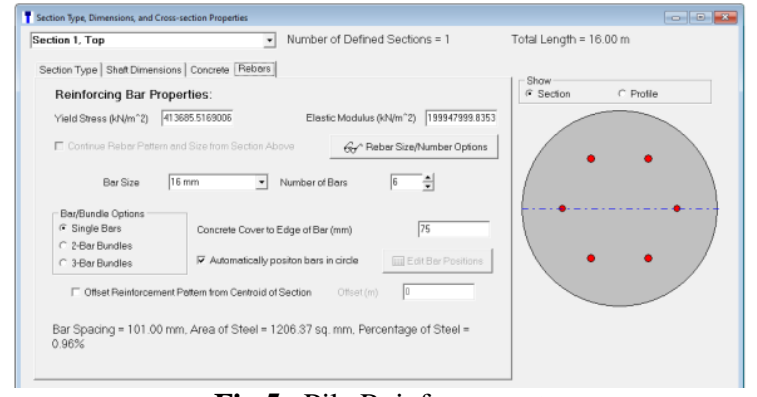

Fig 5 . Pile Reinforcement

2. Insert the lateral load

In this study, 2 cases were given to the head of the load to be able to see the different results in these 2 cases after being analyzed in the application.

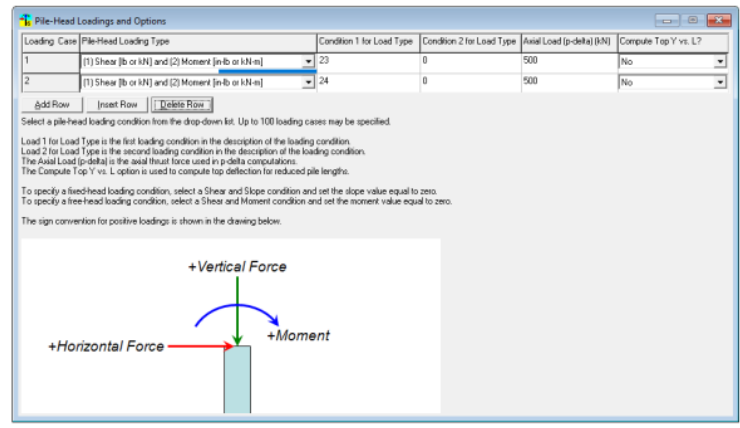

Fig 6. Pile head Loading

3. Enter soil data

In this data, the data included are soil type, base layer height and soil layer data.

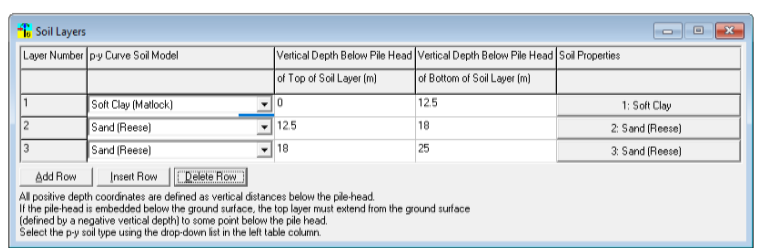

Fig 7. Soil data

There are 3 layers of soil according to the picture above, each layer will enter data such as effective weight, undrained shear strength, $\varepsilon 50$ following the depth of each.

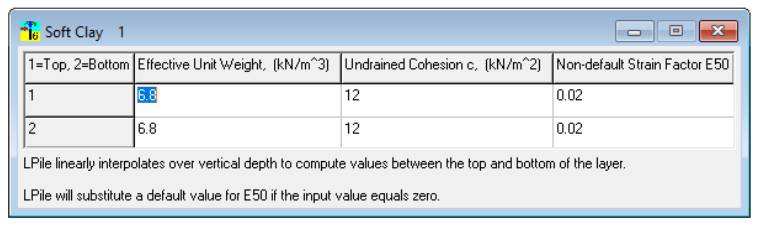

Fig 8. Soil Layer 1 


\section{References}

[1] P. C. Stenning and C. D. Shearing, "Corporate justice: Some preliminary thoughts," Aust. N. Z. J. Criminol., 1984, doi: $10.1177 / 000486588401700203$.

[2] A. Teleman et al., "Altered Growth and Cell Walls in a of Arabidopsis Fucose-Deficient Mutant," Plant Physiol., 2012, doi: 10.1104/pp.110.160051.

[3] K. Ho, "Piling engineering," Eng. Geol., 1995, doi: 10.1016/0013-7952(95)90016-0.

[4] Y. Kim and S. Jeong, "Analysis of soil resistance on laterally loaded piles based on 3D soil-pile interaction," Comput. Geotech., 2011, doi: 10.1016/j.compgeo.2010.12.001

[5] P. Barbaro et al., "Safety Data Sheet," J. Am. Chem. Soc., 2009, doi: 10.1021/jm701266y.

[6] C. P. Tan and Y. B. Che Man, "Differential scanning calorimetric analysis of edible oils: Comparison of thermal properties and chemical composition," JAOCS, J. Am. Oil Chem. Soc., 2000, doi: 10.1007/s11746-000-0024-6.

[7] P. Kah and J. Martikainen, "Influence of shielding gases in the welding of metals," Int. J. Adv. Manuf. Technol., 2013, doi: 10.1007/s00170-012-4111-6.

[8] Y. Zhang, M. J. Cassidy, and B. Bienen, "A plasticity model for spudcan foundations in soft clay,” Can. Geotech. J., 2014, doi: 10.1139/cgj-2013-0269.

[9] J. B. Stevens and J. M. E. Audibert, "Re-examination of p-y curve formulations," in Proceedings of the Annual Offshore Technology Conference, 1979, doi: 10.4043/3402-ms.

[10] M. Ashour and H. Ardalan, "P-y curve and lateral response of piles in fully liquefied sands," Can. Geotech. J., 2012, doi: 10.1139/T2012-019. 